\title{
The Effect of Varying Arterial Oxygen Tension on Neonatal Acid-Base Balance
}

\author{
SHONA M. TORRANCE AND CARIN WITTNICH
}

Departments of Surgery and Physiology, University of Toronto, Toronto, Ontario, Canada

\begin{abstract}
Acute severe hypoxia, when the arterial partial pressure of $\mathrm{O}_{2}\left(\mathrm{PaO}_{2}\right)$ is sufficiently reduced, causes a shift from aerobic to anaerobic metabolism and can be fatal to neonates. The ability of the neonate to accommodate this shift, and prevent acidosis, could play a role in its ability to tolerate hypoxia. This study examines the effect of varying degrees of acute hypoxia on acid-base homeostasis in the neonate using a model of right to left shunting where $\mathrm{PaO}_{2}$ is decreased and, if severe, arterial partial pressure of $\mathrm{CO}_{2}$ is increased. Three-d-old swine were anesthetized, intubated, and mechanically ventilated. Ventilation with a gas mixture of medical air and 95\% $\mathrm{N}_{2}: 5 \%$ $\mathrm{CO}_{2}$ resulted in four groups: 1$)$ normoxia $\left.(n=5) ; 2\right)$ mild hypoxia $(n=4) ; 3)$ moderate hypoxia $(n=3)$; and 4$)$ severe hypoxia $(n=5)$, with $\mathrm{PaO}_{2}$ of $10.7,8.0,5.3$, and $2.7 \mathrm{kPa}(80,60,40$, and $20 \mathrm{~mm} \mathrm{Hg})$, respectively. Acidbase status was evaluated via changes in arterial blood partial pressure of $\mathrm{CO}_{2}, \mathrm{pH}, \mathrm{HCO}_{3}^{-}$, and base excess at $0,30,60$, and $120 \mathrm{~min}$. Only the severe hypoxia group had significantly elevated $(\boldsymbol{p}<0.0001)$ arterial partial pressure of $\mathrm{CO}_{2}$ compared to the other groups at 60 and $120 \mathrm{~min}$ $[8.7 \pm 0.5$ and $8.0 \pm 0.5 \mathrm{kPa}(65.5 \pm 3.7$ and $60.0 \pm 3.7$ $\mathrm{mm} \mathrm{Hg}$ ), respectively]. Base excess was unaltered in the normoxic and mild and moderate hypoxic groups, indicating no change in metabolic acid-base status. The severe hypoxic group had progressively decreased $\mathrm{HCO}_{3}{ }^{-}$, base excess, and $\mathrm{pH}$ at 60 and $120 \mathrm{~min}$. Thus, neonates maintained acid-base homeostasis with a wide range of $\mathrm{PaO}_{2}$ from 12.0 to $5.3 \mathrm{kPa}(90$ to $40 \mathrm{~mm} \mathrm{Hg})$, although progressive acidosis occurred when the $\mathrm{PaO}_{2}$ was further decreased to $2.7 \mathrm{kPa}(20 \mathrm{~mm} \mathrm{Hg})$. (Pediatr Res 31: 112-116, 1992)
\end{abstract}

\section{Abbreviations}

$\mathrm{PaO}_{2}$, arterial partial pressure of oxygen

$\mathrm{PaCO}_{2}$, arterial partial pressure of carbon dioxide $\mathrm{HCO}_{3}^{-}$, bicarbonate

$\mathrm{BE}$, base excess

$\mathrm{FrO}_{2}$, fractional inspired oxygen concentration $\mathrm{FiCO}_{2}$, fractional inspired carbon dioxide concentration $\mathrm{HbF}$, fetal hemoglobin

Hypoxia challenges an organism to maintain normal function under reduced oxygen conditions. Progressive alveolar hypoventilation or venous admixture from pulmonary abnormalities, heart defects, or other conditions that impair gas exchange can also result in increased $\mathrm{PaCO}_{2}$ concurrent with the severity of neonatal hypoxia, depending on the degree of shunting $(1,2)$.

Received May 30, 1991; accepted September 9, 1991.

Correspondence and reprint requests: Dr. C. Wittnich, St. Michael's Hospital, 30 Bond Street, Room 806F, Toronto, Ontario, M5B 1W8 Canada.

Supported by a grant from the Heart and Stroke Foundation of Ontario.
Premature closure of the ductus arteriosus in cyanotic congenital heart patients with tetralogy of Fallot can cause acute, profound hypoxia, and survival under these conditions is not only a function of oxygenation but could be complicated by acidemia resulting from increased $\mathrm{H}^{+}$production (3). Hypoxia-induced acidosis, determined by the extent of tissue hypoxia $(4,5)$, is primarily caused by anaerobic ATP hydrolysis and anaerobic glycolysis secondary to severe $\mathrm{O}_{2}$ reductions (6-8). Persistent fetal adaptations to the hypoxic environment in utero may influence the neonate's ability to cope with hypoxia postpartum. For example, the enhanced oxygen carrying capacity of neonatal blood will ultimately determine tissue oxygen delivery, thus controlling the development of hypoxia-induced acidosis (9).

This study examines the effect of varying degrees of acute hypoxia on neonatal acid-base homeostasis to determine the range of $\mathrm{PaO}_{2}$ under which 1 ) completely normal acid-base status can be maintained; 2) compensation can maintain normal status; and 3) the organism is unable to compensate. Aberrations in acid-base homeostasis in this experiment are indicative of stress and the efficiency of the compensatory buffering mechanisms. Parameters used to analyze acid-base homeostasis include $\mathrm{PaCO}_{2}$ arterial $\mathrm{pH}, \mathrm{HCO}_{3}^{-}$, and $\mathrm{BE}$.

\section{MATERIALS AND METHODS}

Preparation. Neonatal (3-d-old) male Yorkshire swine ( $n=$ 17) were anesthetized with an intraperitoneal injection of sodium pentobarbital $(65 \mathrm{mg} / \mathrm{mL}, 1 \mathrm{~mL} / \mathrm{kg}$ ), intubated, and mechanically ventilated with medical air. Anesthesia was maintained by supplemental i.v. bolus injections of dilute pentobarbital (32.5 $\mathrm{mg} / \mathrm{mL}$ ) as necessary. All animals received humane care in accordance with National Institute of Health and Canadian Council on Animal Care guidelines.

The right carotid artery was isolated and a catheter inserted and advanced to the aortic arch to monitor arterial blood pressures, obtain arterial blood samples, and administer fluids. A pressure line was connected to a transducer (Bell and Howell Instruments, Pasadena, CA) and a Honeywell AR6 simultrace recorder (Honeywell Information Systems, Pleasantville, NY). Blood volume losses were replaced with equal volumes of isotonic saline $(0.9 \% \mathrm{NaCl})$ after each sample withdrawal, and animals maintained normal hematocrits throughout the experiment. Normothermia $\left(37.6 \pm 0.2^{\circ} \mathrm{C}\right)$ was maintained in each piglet.

Serial blood samples were obtained at time 0 (control) and at 30,60 , and 120 min of hypoxia and were analyzed on a Corning $178 \mathrm{pH} /$ blood gas analyzer. The $\mathrm{PaO}_{2}$ was directly determined via a Clark oxygen electrode, and glass electrodes were used to determine $\mathrm{pH}$ and $\mathrm{PaCO}_{2}$ via the methodology of Stow and Severinghaus (10-12). All blood analyzer measurements were corrected for the animal's body temperature $\left(37.6 \pm 0.2^{\circ} \mathrm{C}\right)$. The remaining two parameters, $\mathrm{HCO}_{3}{ }^{-}$and $\mathrm{BE}$, were calculated using standard curves. The $\mathrm{HCO}_{3}{ }^{-}$concentration was calculated via the standard Van Slyke and Cullin $(13,14)$ formula. The BE, the amount of acid or base required to titrate $1 \mathrm{~L}$ of blood to a $\mathrm{pH}$ of 7.40, was calculated using the Siggaard-Andersen formula 
(15). This method of determining BE was originally calculated for human arterial blood with a $\mathrm{PaCO}_{2}$ of $5.3 \mathrm{kPa}(40 \mathrm{~mm} \mathrm{Hg})$, $\mathrm{pH}$ of 7.4 , and $\mathrm{HCO}_{3}{ }^{-}$of $24.5 \mathrm{mmol} / \mathrm{L}$. The validity of this method for pigs has been questioned. Nomograms that are significantly different from those calculated from the SiggaardAndersen formula have been constructed for porcine blood where $\mathrm{PaCO}_{2}$ was $5.3 \mathrm{kPa}(40 \mathrm{~mm} \mathrm{Hg})$, pH was 7.50 , and $\mathrm{HCO}_{3}{ }^{-}$ was $31.6 \mathrm{mmol} / \mathrm{L}(16)$. Note the significantly higher $\mathrm{pH}$ and $\mathrm{HCO}_{3}{ }^{-}$at similar $\mathrm{PaCO}_{2}$ for pigs. However, the blood biochemistry of the piglets used in these experiments had a $\mathrm{PaCO}_{2}$ of 4.8 $\mathrm{kPa}(35.9 \mathrm{~mm} \mathrm{Hg})$. With values adjusted to a $\mathrm{PaCO}_{2}$ of 40 , a pH of 7.45 and $\mathrm{HCO}_{3}{ }^{-}$of $27.2 \mathrm{mmol} / \mathrm{L}$ resulted. Although the piglet $\mathrm{pH}$ is intermediate between the human and adult pig, the piglet $\mathrm{HCO}_{3}{ }^{-}$is much closer to the human value. In addition to this, the hypoxia group $\mathrm{pH}$ values deviate even further from the adult porcine values toward those of humans; thus, BE corrections for swine blood were not required.

Protocol. All values are expressed in SI units and followed by standard units where required. Control measurements of each piglet ventilated with medical air verified normal blood parameters $\left[\mathrm{PaO}_{2}=11.1 \pm 0.2 \mathrm{kPa}(83.1 \pm 1.7 \mathrm{~mm} \mathrm{Hg}), \mathrm{PaCO}_{2}=4.8\right.$ $\pm 0.2 \mathrm{kPa}(35.9 \pm 1.4 \mathrm{~mm} \mathrm{Hg}), \mathrm{pH}=7.48 \pm 0.02, \mathrm{HCO}_{3}{ }^{-}=$ $27.2 \pm 0.5 \mathrm{mmol} / \mathrm{L}$, and $\mathrm{BE}=4.7 \pm 0.6 \mathrm{mmol} / \mathrm{L}]$. Animals outside these ranges were excluded from the study. Ventilatory parameters were established during the normoxic period and were only altered during the hypoxic phase to maintain $\mathrm{PaO}_{2}$ within the desired range. Hypoxemia resulted from adding $95 \%$ $\mathrm{N}_{2}: 5 \% \mathrm{CO}_{2}$ to the medical air, thus reducing the $\mathrm{FrO}_{2}$. The appropriate mix of gases required for each animal was determined by measuring the $\mathrm{PaO}_{2}$. Normoxic $(n=5)$ and mild $(n=$ $4)$, moderate $(n=3)$, and severe $(n=5)$ hypoxic groups resulted, with a mean $\mathrm{PaO}_{2}$ of $11.1 \pm 0.3,7.5 \pm 0.1,5.4 \pm 0.2$, and $3.1 \pm$ $0.1 \mathrm{kPa}(83.4 \pm 2.2,56.0 \pm 1.0,40.2 \pm 1.5$, and $23.1 \pm 1.0 \mathrm{~mm}$ $\mathrm{Hg}$ ), respectively, throughout the study period. $\mathrm{FrCO}_{2}$ increased slightly with the hypercapnic gas mixture, yet remained below $1 \%$ (normoxia $=0.04 \%$, mild hypoxia $=0.19 \%$, moderate hypoxia $=0.74 \%$, severe hypoxia $=0.81 \%$ ). In the most extreme case, the small increase in $\mathrm{FICO}_{2}$ in the severe hypoxic group would only cause a $0.8 \mathrm{kPa}(6.2 \mathrm{~mm} \mathrm{Hg})$ rise in $\mathrm{PaCO}_{2}(17)$. This increase would be rapid and would plateau without additional increases over time at each level of hypoxia.

Analysis. Results are expressed as mean \pm SEM in SI units and followed by standard units where required. Statistical analysis was performed by two-way analysis of variance with Duncan's multiple range test for significance (18). Bonferroni correction factor for multiple comparisons was used to determine the appropriate $p$ level for statistical significance (19). Statistical significance was accepted at $p<0.0014$ for the $\mathrm{PaO}_{2}$ analysis and $p<$ 0.0010 for all other parameters $\left(\mathrm{PaCO}_{2}, \mathrm{pH}, \mathrm{HCO}_{3}{ }^{-}\right.$, and $\left.\mathrm{BE}\right)$. All groups were compared to one another at each time interval, and each group was compared across time $(0,30,60$, and 120 min). Time 0 (control) was not included in the across-time $\mathrm{PaO}_{2}$ analysis because the animals had not yet been allocated into the study groups and, thus, a slightly higher level was required for significance.

\section{RESULTS}

$\mathrm{PaO}_{2}$ in the four groups are shown in Table 1. Retrospective analysis at control (time 0 ) ensured that the groups were not different $\left[\mathrm{PaO}_{2}=11.1 \pm 0.2 \mathrm{kPa}(83.1 \pm 1.6 \mathrm{~mm} \mathrm{Hg})\right]$. During the 2-h experimental-period, mean $\mathrm{PaO}_{2}$ for the four groups were: normoxia $11.1 \pm 0.3 \mathrm{kPa}(83.4 \pm 2.2 \mathrm{~mm} \mathrm{Hg})$, mild hypoxia 7.5 $\pm 0.1 \mathrm{kPa}(56.0 \pm 1.0 \mathrm{~mm} \mathrm{Hg})$, moderate hypoxia $5.4 \pm 0.2 \mathrm{kPa}$ $(40.2 \pm 1.5 \mathrm{~mm} \mathrm{Hg})$, and severe hypoxia $3.1 \pm 0.1 \mathrm{kPa}(23.1 \pm$ $1.0 \mathrm{~mm} \mathrm{Hg}$ ). There was no significant change in the $\mathrm{PaO}_{2}$ of any of the groups from 30 to $120 \mathrm{~min}$, except in the normoxic group, which had a nonphysiologic decline at $120 \mathrm{~min}$ to $10.4 \pm 0.1$ $\mathrm{kPa}(77.8 \pm 0.7 \mathrm{~mm} \mathrm{Hg})$. At both 30 and $60 \mathrm{~min}$, all ventilated groups were significantly different from each other $(p<0.0001)$.
All groups were significantly different $(p<0.0005)$ at $120 \mathrm{~min}$, except for a slight increase in $\mathrm{PaO}_{2}$ in the severe hypoxia group $[3.4 \pm 0.2 \mathrm{kPa}(25.8 \pm 1.2 \mathrm{~mm} \mathrm{Hg})]$ and a slight decrease in the moderate hypoxia group $[5.0 \pm 0.8 \mathrm{kPa}(37.8 \pm 5.9 \mathrm{~mm} \mathrm{Hg})]$.

$\mathrm{PaCO}_{2}$. Changes in $\mathrm{PaCO}_{2}$ with varying degrees of hypoxia are shown in Table 2. The baseline $\mathrm{PaCO}_{2}$ of all groups at control was $4.8 \pm 0.2 \mathrm{kPa}(35.9 \pm 1.4 \mathrm{~mm} \mathrm{Hg})$. There was no change in $\mathrm{PaCO}_{2}$ in the mild hypoxic group despite a slight increase in $\mathrm{FICO}_{2}$ $(0.19 \%)$. The moderate group $\left(\mathrm{FICO}_{2}=0.74 \%\right)$ had a slightly higher $\mathrm{PaCO}_{2}$ compared to the normoxic group at $30 \mathrm{~min}[6.2 \pm$ $0.2 \mathrm{kPa}(46.8 \pm 1.7 \mathrm{~mm} \mathrm{Hg}), p<0.0001]$, but this was not significantly different from control. With severe hypoxia $\left(\mathrm{FrCO}_{2}\right.$ $=0.81 \%$ ), $\mathrm{PaCO}_{2}$ had increased significantly by $30 \mathrm{~min}$, compared to its control value and the normoxic and mild hypoxic groups at this time $[7.1 \pm 0.3 \mathrm{kPa}(53.1 \pm 2.4 \mathrm{~mm} \mathrm{Hg}), p<0.0001]$. Additional significant increases in $\mathrm{PaCO}_{2}$ occurred at $60 \mathrm{~min}$ [8.7 $\pm 0.5 \mathrm{kPa}(65.5 \pm 3.7 \mathrm{~mm} \mathrm{Hg}), p<0.0005]$ and persisted at 120 $\min [8.0 \pm 0.5 \mathrm{kPa}(60.0 \pm 3.7 \mathrm{~mm} \mathrm{Hg}), p<0.0001]$. These values were well above levels due to increased $\mathrm{FICO}_{2}$ alone $[0.8$ $\mathrm{kPa}(6.2 \mathrm{~mm} \mathrm{Hg})$ rise]. Thus, although the mild and moderate hypoxic groups had unaltered $\mathrm{PaCO}_{2}$, the severe hypoxic group had progressive hypercapnia, which peaked at $60 \mathrm{~min}$ and was maintained at $120 \mathrm{~min}$.

$p H$. The mean control $\mathrm{pH}$ for all experimental groups was $7.48 \pm 0.02$. There was no significant alteration in $\mathrm{pH}$ with normoxia or mild or moderate hypoxia (Fig. 1) despite a slight decrease in the moderate group at $30 \mathrm{~min}$. The severe hypoxic group had a significant decrease in $\mathrm{pH}$ compared to the normoxic group at $30 \mathrm{~min}(7.33 \pm 0.03, p<0.0001)$. The $\mathrm{pH}$ declined significantly and progressively in severe hypoxia, compared to the 30 -min value, at $60(7.14 \pm 0.08, p<0.0001)$ and $120 \mathrm{~min}$ $(7.04 \pm 0.13, p<0.0001)$. Thus, hypoxia induced no significant change in $\mathrm{pH}$ in the mild and moderate groups, whereas severe hypoxia resulted in progressive, uncontrolled acidosis.

$\mathrm{HCO}_{3}{ }^{-}$. Sodium bicarbonate is the primary blood buffer, and decreased concentrations indicate its consumption to neutralize acid released during metabolic acidosis. The mean $\mathrm{HCO}_{3}{ }^{-}$for all groups at control, before the induction of hypoxia, was $27.2 \pm$ $0.5 \mathrm{mmol} / \mathrm{L}$. The normoxic and mild and moderate hypoxic groups had no difference in $\mathrm{HCO}_{3}{ }^{-}$at any time interval (Fig. 2). The severe hypoxic group had a progressive decrease in $\mathrm{HCO}_{3}{ }^{-}$, compared to the 0 - and 30 -min values, at $60 \mathrm{~min}(22.8 \pm 2.9$ $\mathrm{mmol} / \mathrm{L}, p<0.0001)$, and it was further reduced at $120 \mathrm{~min}$ $(16.4 \pm 3.1 \mathrm{mmol} / \mathrm{L}, p<0.0001)$. Thus, the normoxic and mild and moderate hypoxic groups maintain normal $\mathrm{HCO}_{3}^{-}$, whereas the severe hypoxic group had a significant progressive reduction in $\mathrm{HCO}_{3}^{-}$throughout the experiment.

$B E$. $\mathrm{BE}$ is an indicator of the metabolic acid-base status of a system. Mean control BE for all animals was $4.7 \pm 0.6 \mathrm{mmol} / \mathrm{L}$. $\mathrm{BE}$ did not change in the normoxic or mild and moderate hypoxic groups (Fig. 3). In the severe hypoxic group at $60 \mathrm{~min}$, $\mathrm{BE}$ was significantly reduced compared to all groups and the 0 and 30-min severe hypoxic group values $(-7.9 \pm 4.4 \mathrm{mmol} / \mathrm{L}, p$ $<0.0001)$. There was a further significant decline in $\mathrm{BE}$ at 120 $\min (-15.7 \pm 5.8 \mathrm{mmol} / \mathrm{L}, p<0.0001)$. Thus, the normoxic and mild and moderate hypoxic groups had unaltered $\mathrm{BE}$, whereas a significant progressive decline occurred in the severe hypoxic group.

In the neonate, acid-base homeostasis was maintained from normoxia to moderate hypoxia. In severe hypoxia, hypercapnia developed, peaked at $60 \mathrm{~min}$, and was accompanied by progressive metabolic acidosis at 60 and $120 \mathrm{~min}$, as determined by arterial $\mathrm{pH}, \mathrm{HCO}_{3}^{-}$, and $\mathrm{BE}$.

\section{DISCUSSION}

This model of hypoxia used a hypercapnic gas mixture that increased $\mathrm{FiCO}_{2}$ for each level of hypoxia up to $0.81 \%$ in the severe hypoxic group. At that level, the ventilatory gas mix would only induce a $0.8-\mathrm{kPa}(6.2-\mathrm{mm} \mathrm{Hg})$ rise in $\mathrm{PaCO}_{2}(17)$. This 
Table 1. $\mathrm{PaO}_{2}$ comparisons of neonates with normoxia and mild, moderate, and severe hypoxia*

\begin{tabular}{|c|c|c|c|c|c|}
\hline & \multirow[b]{2}{*}{$n$} & \multicolumn{4}{|c|}{ Time (min) } \\
\hline & & 0 & 30 & 60 & 120 \\
\hline Normoxia & 5 & $\begin{array}{c}11.7 \pm 0.5 \\
(88.0 \pm 4.1)\end{array}$ & $\begin{array}{c}11.9 \pm 0.5 \dagger \\
(89.0 \pm 4.0)\end{array}$ & $\begin{array}{c}11.0 \pm 0.5 \dagger \\
(82.2 \pm 3.5)\end{array}$ & $\begin{array}{l}10.4 \pm 0.1 \dagger \ddagger \\
(77.8 \pm 0.7)\end{array}$ \\
\hline \multicolumn{6}{|l|}{ Hypoxia } \\
\hline Mild & 4 & $\begin{array}{c}11.6 \pm 0.5 \\
(87.2 \pm 4.0)\end{array}$ & $\begin{array}{r}7.5 \pm 0.2 \dagger \\
(56.5 \pm 1.5)\end{array}$ & $\begin{array}{r}7.4 \pm 0.1 \dagger \\
(55.4 \pm 0.7)\end{array}$ & $\begin{array}{r}6.9 \pm 0.1 \S \\
(52.1 \pm 0.4)\end{array}$ \\
\hline Moderate & 3 & $\begin{array}{c}10.3 \pm 0.3 \\
(77.1 \pm 2.2)\end{array}$ & $\begin{array}{r}5.4 \pm 0.2 \dagger \\
(40.5 \pm 1.4)\end{array}$ & $\begin{array}{r}5.5 \pm 0.2 \dagger \\
(41.6 \pm 1.7)\end{array}$ & $\begin{array}{r}5.0 \pm 0.8 \| \\
(37.8 \pm 5.9)\end{array}$ \\
\hline Severe & 5 & $\begin{array}{c}10.6 \pm 0.3 \\
(79.3 \pm 1.9) \\
\end{array}$ & $\begin{array}{r}3.0 \pm 0.2 \dagger \\
(22.6 \pm 1.4) \\
\end{array}$ & $\begin{array}{r}3.0 \pm 0.2 \dagger \\
(22.5 \pm 1.6) \\
\end{array}$ & $\begin{array}{r}3.4 \pm 0.29 \\
(25.8 \pm 1.2) \\
\end{array}$ \\
\hline
\end{tabular}

* Values are mean $\pm \mathrm{SEM} \mathrm{kPa}(\mathrm{mm} \mathrm{Hg})$. Statistical analysis via two-way analysis of variance with Duncan's multiple range test post hoc for significance and significance accepted for $p<0.0014$.

$\dagger$ Different from all others at same interval, $p<0.0001$.

$\ddagger$ Different from the 30 -min value of the same group, $p<0.0005$.

$\S$ Different from all others at same interval, $p<0.0014$.

$\|$ Different from all other groups except severe at the same time interval, $p<0.0014$.

II Different from all other groups except moderate at the same time interval, $p<0.0001$.

Table 2. $\mathrm{PaCO}_{2}$ comparisons of neonates with normoxia and mild, moderate, and severe hypoxia*

\begin{tabular}{|c|c|c|c|c|c|}
\hline & \multirow[b]{2}{*}{$n$} & \multicolumn{4}{|c|}{ Time (min) } \\
\hline & & 0 & 30 & 60 & 120 \\
\hline $\begin{array}{l}\text { Normoxia } \\
\text { Hypoxia }\end{array}$ & 5 & $\begin{array}{c}4.7 \pm 0.6 \\
(35.6 \pm 4.2)\end{array}$ & $\begin{array}{c}4.4 \pm 0.4 \\
(32.7 \pm 3.3)\end{array}$ & $\begin{array}{c}4.7 \pm 0.3 \\
(35.3 \pm 2.5)\end{array}$ & $\begin{array}{c}5.0 \pm 0.3 \\
(37.6 \pm 2.1)\end{array}$ \\
\hline Mild & 4 & $\begin{array}{c}4.5 \pm 0.2 \\
(33.8 \pm 1.3)\end{array}$ & $\begin{array}{c}4.6 \pm 0.2 \\
(34.3 \pm 1.6)\end{array}$ & $\begin{array}{c}4.9 \pm 0.3 \\
(36.5 \pm 2.3)\end{array}$ & $\begin{array}{c}4.9 \pm 0.3 \\
(37.1 \pm 2.4)\end{array}$ \\
\hline Moderate & 3 & $\begin{array}{c}4.8 \pm 0.1 \\
(36.1 \pm 1.0)\end{array}$ & $\begin{array}{r}6.2 \pm 0.2 \dagger \\
(46.8 \pm 1.7)\end{array}$ & $\begin{array}{c}5.8 \pm 0.2 \\
(43.5 \pm 1.7)\end{array}$ & $\begin{array}{r}5.2 \pm 0.6 \pi \\
(38.7 \pm 4.4)\end{array}$ \\
\hline Severe & 5 & $\begin{array}{c}5.0 \pm 0.2 \\
(37.4 \pm 1.2)\end{array}$ & $\begin{array}{c}7.1 \pm 0.3 \neq \S \\
(53.1 \pm 2.4)\end{array}$ & $\begin{array}{c}8.7 \pm 0.5 \ddagger \| \uparrow \\
(65.5 \pm 3.7)\end{array}$ & $\begin{aligned} 8.0 & \pm 0.5 \neq 11 \\
(60.0 & \pm 3.7)\end{aligned}$ \\
\hline
\end{tabular}

* Values are mean $\pm \mathrm{SEM} \mathrm{kPa}(\mathrm{mm} \mathrm{Hg})$. Statistical analysis via two-way analysis of variance with Duncan's multiple range test post hoc for significance and significance accepted for $p<0.0010$.

$\dagger$ Different from normoxia at the same time interval, $p<0.0001$.

$\ddagger$ Different from the time 0 value of the same group, $p<0.0001$.

$\S$ Different from all other groups except moderate at the same time interval, $p<0.0001$.

$\|$ Different from all others at same interval, $p<0.0001$.

II Different from the 30-min value of the same group, $p<0.0005$.

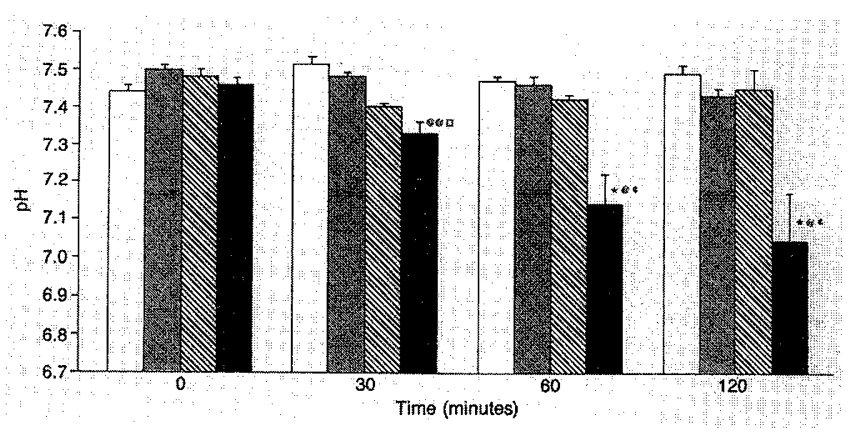

Fig. 1. Arterial $\mathrm{pH}$ with varying degrees of neonatal hypoxia. Groups shown are normoxia (open bars), mild hypoxia (gray bars), moderate hypoxia (hatched bars), and severe hypoxia (black bars). Normal range is $7.48 \pm 0.02$. Values are mean \pm SEM. ${ }^{*}, p<0.0001$, statistically different from all others at same interval; $\square, p<0.0001$, different from normoxia at the same time interval; @, $p<0.0001$, @@, $p<0.0005$, different from the time 0 value of the same group; and $\Phi, p<0.0001$, different from the 30-min value of the same group.

would occur very rapidly, before the $30-\mathrm{min}$ blood analysis, stabilizing to a new plateau for the remainder of the experiment as a result of fixed ventilator settings. Increases in $\mathrm{PaCO}_{2}$ subsequent to the $30-\mathrm{min}$ blood analysis cannot be attributed to the increased $\mathrm{FiCO}_{2}$.
The hypoxia, which when severe was accompanied by hypercapnia, corresponds clinically to pulmonary or cardiac abnormalities that cause either alveolar hypoventilation or progressive venous admixture. Newborn respiratory distress syndrome, due to many possible conditions including cor pulmonale, upper airway obstruction, neuromuscular diseases, asphyxia, pneumonia, and pulmonary air leak, causes concurrent profound hypoxemia $(2,20)$. This hypoxic/hypercarbic relationship is also characteristic of congenital cardiac anomalies inducing right to left shunts and progressive venous admixture proportional to the size of the shunt and include tetralogy of Fallot, tricuspid atresia, and transposition of the great arteries. These conditions all cause moderate to severe hypoxia with small arteriovenous $\mathrm{CO}_{2}$ differences. In preductal coarctation of the aorta, for instance, extensive right to left shunting via the ductus arteriosus typically causes a $\mathrm{PaO}_{2}$ of $2.0-4.0 \mathrm{kPa}(15-30 \mathrm{~mm} \mathrm{Hg})$ and a $\mathrm{PaCO}_{2}$ of $6.7-8.0 \mathrm{kPa}(50-60 \mathrm{~mm} \mathrm{Hg})(1)$, which correlates with the severe hypoxic group in this study.

The fetal environment in utero is profoundly hypoxic with a fetal $\mathrm{PaO}_{2}$ of $4.0 \mathrm{kPa}(30 \mathrm{~mm} \mathrm{Hg})(21)$. Fetal adaptations to survive this profound hypoxia include: 1 ) $\mathrm{HbF}$, which shifts the oxygen dissociation curve to the left, increasing blood oxygen carrying capacity $(4,5) ; 2$ ) elevated $\mathrm{Hb}$ concentration enhancing tissue oxygen transport $(22,23)$; and 3 ) the "double Bohr effect," which regulates transplacental gas exchange, enhancing oxygen uptake by the fetal blood (21). Some of these adaptations, such 


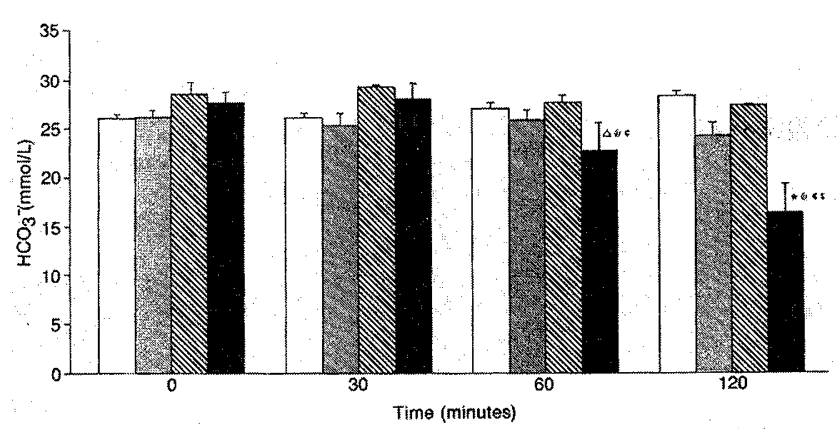

Fig. 2. Arterial $\mathrm{HCO}_{3}{ }^{-}$with varying degrees of neonatal hypoxia. Groups shown are normoxia (open bars), mild hypoxia (gray bars), moderate hypoxia (hatched bars), and severe hypoxia (black bars). Normal range is $27.2 \pm 0.5 \mathrm{mmol} / \mathrm{L}$. Values are mean $\pm \mathrm{SEM} .{ }^{*}, p<$ 0.0001 , statistically different from all others at same interval; $\Delta, p<$ 0.0005 , different from all other groups except mild at the same time interval; @, $p<0.0001$, different from the time 0 value of the same group; $₫, p<0.0001$, different from the 30 -min value of the same group; and $\$, p<0.0001$, different from the 60 -min value of the same group.

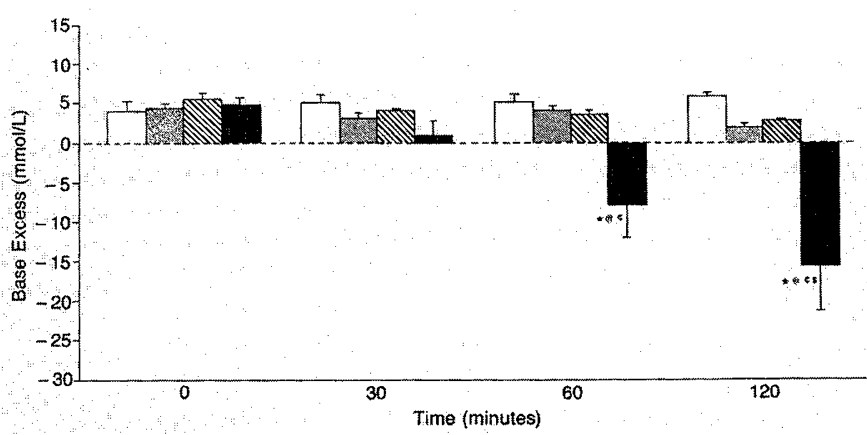

Fig. 3. Arterial BE with varying degrees of neonatal hypoxia. Groups shown are normoxia (open bars), mild hypoxia (gray bars), moderate hypoxia (hatched bars), and severe (black bars). Normal range is $4.7 \pm$ $0.6 \mathrm{mmol} / \mathrm{L}$. Values are mean \pm SEM. ${ }^{*}, p<0.0001$, statistically different from all others at same interval; @, $p<0.0001$, different from the time 0 value of the same group; $\Phi, p<0.0001$, different from the 30 -min value of the same group; and $\$, p<0.0001$, different from the 60 -min value of the same group.

as the presence of $\mathrm{HbF}$ and high $\mathrm{Hb}$ concentrations, persist during the early postnatal period (24), increase the total oxygen carrying capacity of the blood, and are important in the neonate's tolerance of hypoxia (9). The enhanced oxygen affinity of $\mathrm{HbF}$ may actually impair oxygen delivery in mild and moderate hypoxia (25). During exposure to severe hypoxia, however, this high blood oxygen affinity is beneficial because it increases blood oxygen carrying capacity despite profoundly reduced oxygen availability $(25,26)$. The increased oxygen affinity of neonatal blood controls the extent of tissue hypoxia and thus determines the neonate's ability to maintain acid-base homeostasis despite a wide range of reduced systemic oxygen tensions.

Profound hypoxia can effect acid-base balance through a shift from aerobic to anaerobic metabolism. This occurs by indirect inhibition of the Kreb's cycle $(6,27-29)$ as a result of reduced $\mathrm{NAD}^{+}$supply. When oxygen is sufficiently reduced, inhibition of the mitochondrial electron transport chain impairs mitochondrial oxidation, which, in turn, prevents supply of $\mathrm{NAD}^{+}$essential for the Kreb's cycle (30). This inhibition causes a shift in metabolism from aerobic to anaerobic glycolysis with net blood lactate and $\mathrm{H}^{+}$production (6-8).

The carbonic acid $\left(\mathrm{H}_{2} \mathrm{CO}_{3}\right) / \mathrm{HCO}_{3}{ }^{-}$buffering system is described by the following equilibrium:

$$
\mathrm{HCO}_{3}^{-}+\mathrm{H}^{+} \leftrightarrow \mathrm{H}_{2} \mathrm{CO}_{3} \leftrightarrow \mathrm{CO}_{2}+\mathrm{H}_{2} \mathrm{O}
$$

Decreases in the blood $\mathrm{HCO}_{3}{ }^{-}$concentration indicate the use of this buffer to neutralize acid as observed in severe hypoxia. When $\mathrm{H}^{+}$enters the system, as it does with metabolic acidosis, $\mathrm{HCO}_{3}{ }^{-}$ is consumed in an attempt to maintain $\mathrm{pH}$, shifting the equilibrium toward $\mathrm{CO}_{2}$. This was observed in the severe hypoxia group, which decreased $\mathrm{HCO}_{3}{ }^{-}$and increased $\mathrm{PaCO}_{2}$ at 60 and $120 \mathrm{~min}$.

$\mathrm{BE}$ is an indicator of metabolic acid-base status of the buffering system independent of respiratory acidosis or alkalosis (8). The unaltered BE, in all groups at $30 \mathrm{~min}$ and in the normoxic and mild and moderate hypoxic groups at 60 and $120 \mathrm{~min}$, indicates that no significant metabolic acid-base disturbance was present. In the severe hypoxic group, progressive decline in $\mathrm{BE}$ (30 to 60 min and 60 to $120 \mathrm{~min}, p<0.0001$ ) is not attributable to $\mathrm{FICO}_{2}$, but indicates profound hypoxia-induced metabolic acidosis.

Clinical hypercapnia $\left[\mathrm{PaCO}_{2}>6.7 \mathrm{kPa}(50 \mathrm{~mm} \mathrm{Hg})\right]$ only occurred in the severe hypoxic group. The role of hypercapnia on the progression of the acidosis seen in the severe hypoxic group was tested by studying a severely hypoxic $\mathrm{PaCO}_{2}$-controlled group. The two severely hypoxic groups experienced similar degrees of acidosis by 120 min despite a more rapid initial onset of acidosis in the hypercapnic group. In both severe hypoxia groups, $\mathrm{pH}$ decreased progressively, as did $\mathrm{HCO}_{3}^{-}$and $\mathrm{BE}$, indicating an inability to adequately compensate for the hypoxiainduced metabolic acidosis. The additional stress of respiratory acidosis in the hypercapnic group accelerated the initial onset but did not affect the ultimate extent of the observed acidosis. This metabolic acidosis stressed the blood suffering system so profoundly in the severe hypoxic group that additional hypercapnia did not significantly alter blood $\mathrm{pH}$.

Conclusions. When the neonate was exposed to acute hypoxia with a hypercapnic gas mixture, normal acid-base homeostasis was maintained in a wide $\mathrm{PaO}_{2}$ range of $12-5.3 \mathrm{kPa}$ (90-40 mm $\mathrm{Hg}$ ). Further $\mathrm{PaO}_{2}$ reductions to severe hypoxia caused progressive, uncontrolled acidosis, as indicated by the progressively decreased $\mathrm{pH}, \mathrm{HCO}_{3}^{-}$, and, particularly, BE. The additional stress of hypercapnia in this group accelerated but did not exacerbate the deleterious effects of severe hypoxia on neonatal acid-base homeostasis.

Acknowledgments. The authors thank the Department of Biochemistry and Respiratory Therapy at St. Michael's Hospital for their assistance, M. P. Belanger and S. R. Bulley for their technical assistance, and V. Simpson for her secretarial skills. We also acknowledge COBE, Ethicon Ltd., and Becton Dickinson Canada Inc. for their generous contributions to this research.

\section{REFERENCES}

1. Fanaroff AA, Martin RJ 1987 Neonatal-Perinatal Medicine. CV Mosby, St. Louis, pp 639-743

2. Hodson WA, Truog WE 1989 Critical Care of the Newborn. WB Saunders, Philadelphia, pp 52-69

3. Hurst JW, Schlant RC 1990 The Heart, 7th Ed. McGraw-Hill, New York, pp 831-901

4. Brown MS, Phipps RH, Dallman PR 1985 Postnatal changes in fetal hemoglobin, oxygen affinity and 2,3-diphosphoglycerate in previously transfused preterm infants. Biol Neonate 48:70-76

5. Bard H 1975 The postnatal decline of hemoglobin F synthesis in normal fullterm infants. J Clin Invest 55:395-398

6. Arieff AI, DeFronzo RA 1985 Fluid, Electrolyte and Acid-Base Disorders, Vol. 1. Churchill Livingstone, New York, pp 281-309

7. Halperin ML, Goldstein MP 1988 Fluid, Electrolyte and Acid-Base Emergencies. WB Saunders, Philadelphia

8. Golderger E 1986 A Primer of Water, Electrolyte and Acid-Base Syndromes, 7th Ed. Lea \& Febiger, Philadelphia, pp 145-196

9. Sacks LM, Delivoria-Papadopoulos M 1984 Hemoglobin-oxygen interactions. Semin Perinatol 8:168-183

10. Clark LC 1956 Monitor and control of blood and tissue oxygen tensions. Trans Am Soc Artif Intern Organs 2:41-48

11. Bates RG 1964 Determination of pH: Theory and Practice. John Wiley \& Sons, New York

12. Severinghaus JW, Bradley AF 1968 Electrodes for blood $\mathrm{PO}_{2}$ determination. J Appl Physiol 13:515-520

13. Van Slyke DD, Cullen GE 1917 Studies of Acidosis 1. The bicarbonate concentration of blood plasma, its significance and its determination as a measure of acidosis. J Biol Chem 30:289-346 
14. Adams AP, Morgan-Hughes JO, Sykes MK $1967 \mathrm{pH}$ and blood gas analysis: methods of measurement and sources of error using electrode systems. Anaesthesia 22:575-597

15. Siggaard-Andersen O 1966 Titratable acid or base. Ann NY Acad Sci 133:4158

16. Hannon JP 1984 Construction of acid-base aligment nomograms to estimate buffer base and base-excess concentrations in arterial blood from immature pigs. Am J Vet Res 45:1918-1923

17. Farhi LE, Tenney SM 1987 Handbook of Physiology: The Respiratory System. American Physiological Society, Bethesda, MD, pp 113-129

18. Rosner B 1990 Fundamentals of Biostatistics, 3rd Ed. PWS-Kent Publishing, Boston, pp 474-526

19. Glantz SA 1987 Primer of Biostatistics, 2 Ed. McGraw-Hill Information Services, New York, pp 64-100

20. Chernick V, Kendig EL 1990 Kendig's Disorders of the Respiratory Tract in Children. WB Saunders, Philadelphia, pp 683-692

21. Guyton AC 1986 Textbook of Medical Physiology, 7th Ed. WB Saunders, Philadelphia, pp 983-996

22. Terrenato L, Bertilaccio C, Spinelli P, Colombo B 1981 The switch from haemoglobin $\mathrm{F}$ to $\mathrm{A}$ : the time course of qualitative and quantitative variations of haemoglobins after birth. Br J Haematol 47:31-41
23. Colombo B, Kim B, Perez A, Molina C, Terrenato L 1976 The pattern of fetal hemoglobin disappearance after birth. Br J Haematol 32:79-87

24. Phillips HM, Holland BM, Jones JG, Abdel-Moiz AL, Turner TL, Wardrop CAJ 1988 Definitive estimate of rate of hemoglobin switching: measurement of percent hemoglobin $\mathrm{F}$ in neonatal reticulocytes. Pediatr Res 23:595-597

25. Bunn HF, Forget BG 1986 Hemoglobin: Molecular, Genetic and Clinical Aspects. WB Saunders, Philadelphia, pp 91-125

26. Nathan DG, Oski FA 1987 Hematology of Infancy and Childhood, 3rd Ed. WB Saunders, Philadelphia, pp 613-640

27. Goodwin CW, Mela L, Deutsch C, Forster RE, Miller LD, Delivoria-Papadopoulos M 1976 Development and adaptation of heart mitochondrial respiratory chain function in fetus and in newborn. Adv Exp Med Biol 75:713 719

28. Young HH, Shimizu T, Nishioka K, Nakanishi T, Jarmakani JM 1983 Effect of hypoxia and reoxygenation on mitochondrial function in neonatal myocardium. Am J Physiol 245:H998-H1006

29. Orten JM, Neuhaus OW 1982 Human Biochemistry. CV Mosby, St. Louis, pp 226-244

30. Murray RK, Granner DK, Mayes PA, Rodwell VW 1990 Harper's Biochemistry, 22nd Ed. Appleton \& Lange, Norwalk, CT, pp 155-170 